\section{The use of electroconvulsive therapy in Latin America and the Caribbean}

\author{
Itzhak Levav ${ }^{1}$ and René \\ González Uzcátegui ${ }^{1}$
}

Sixty years after its introduction into psychiatry (1), the use of electroconvulsive therapy (ECT) still fuels scientific, ideological, and ethical debate. One well-informed proponent has observed that ECT is probably more enshrouded in myth than any other procedure in medicine (2). Among the population at large, and especially patients and their family members, ECT may be the psychiatric intervention that arouses the most anxiety $(3,4)$-although some authors dispute this assertion (5).

ECT has specific indications, and objective standards and principles guide appropriate administration. In the United States of America, for example, the American Psychiatric Association has issued such standards (3). In that country, efforts have been made to study ECT's indications and effects and to safeguard the rights of patients, but it is interesting to note that the use of ECT has varied over time and geographically. These frequently reported discrepancies underscore ECT's stillprecarious and controversial status in psychiatric care (6-8). Geographical variation in ECT use has also been identified in Great Britain, where it is more common in Ireland than in England (9). Similarly, reports in Uruguay indicate that it is used more in the capital city than in the country's interior (10).

This paper reports the results of a mail survey conducted in 1995 to obtain precise and authoritative data concerning the use of ECT in Latin America and the Caribbean. The objective was to facilitate the identification of psychiatric, administrative, and bioethical issues that will provide, if needed, the basis for action to ensure that ECT is used appropriately.

\section{METHODS}

Directors of the mental health divisions or departments of the ministries of health throughout Latin America and the Caribbean (with the exception of Haiti) were contacted through the Representative Offices of the Pan American Health Organization/World Health Organization. Where ministries lacked such a division or department (as in many Caribbean countries), the survey was directed to the officials responsible for mental health programs or the directors of the national public psychiatric hospital. In one case, the national psychiatric association acted as the respondent.
1 Pan American Health Organization/World Health Organization, Program on Healthy Lifestyles and Mental Health, Washington, D.C., USA. 


\section{RESULTS}

Seventeen of 19 countries contacted in Latin America (89\%) answered the survey in full, and two more provided partial responses. Thirteen of 17 countries or territories in the English- or Dutchspeaking Caribbean (76\%) responded, among them those with the largest populations. Given the different psychiatric traditions of the two groups of countries, the results were analyzed separately.

Every reporting country in Latin America employs ECT, in sharp contrast to the English- and Dutch-speaking Caribbean, where only four use it. In Latin America as well as the Caribbean, use varies from country to country and even within individual countries. As a rule, public institutions use ECT more frequently than do private. A trend away from use of ECT was reported in eight Latin American countries and the two most populous ECT-using countries in the English-speaking Caribbean.

Written technical standards exist in the four Caribbean countries that use ECT, but in only 10 of the 19 Latin American countries. Two additional countries reported that they have developed standards and are seeking approval from national authorities and professional associations.

The use of both anesthesia and muscle relaxants in the administration of ECT is universally recommended $(3,11)$. However, only $26 \%$ of the countries in Latin America reported that anesthesia is given with ECT in all institutions, compared to three of the four Caribbean countries that administer the procedure. In some Latin American countries the use of anesthesia is more frequent in the private sector than in the public. Muscle relaxants are given in all institutions in $32 \%$ of Latin American countries, and in some institutions in another $36 \%$. As with anesthesia, administration of muscle relaxants tends to be more routine in the private than in the public sector.

In only $37 \%$ of Latin American countries do all institutions obtain informed consent for ECT from the patient or authorized individual. In $26 \%$ of the countries informed consent is obtained sometimes, and in another $26 \%$ never. Informed consent is routinely obtained in the four Caribbean countries that administer ECT.

\section{DISCUSSION}

One of the central tenets of the Initiative for Restructuring Psychiatric Care in Latin America (12) — which was launched in an era marked by a restoration of democracy and respect for human rights in the subregion-is the improvement of care through the application of the most advanced scientific and technical knowledge, rational interventions, and humane care for patients and their families. $\mathrm{PAHO} / \mathrm{WHO}$ regularly asks countries for the information it needs to guide the activities of this Initiative and to provide appropriate technical collaboration. An analogous initiative has been launched in the English- and Dutch-speaking Caribbean.

The variations in the use of ECT observed in this survey probably reflect differences in the psychiatric traditions of Latin America and the English- and Dutch-speaking Caribbean, as well as unequal availability of technical resources in different countries, related to the sizes of their populations and territories. The observed decrease in the use of ECT diverges from the apparent trend in the United States today, but parallels that in Italy and Spain. A central item on the ECT research agenda should be a comparison of the outcomes obtained when this procedure is used as a principal intervention versus other approaches that replace it. Other questions of interest concern how the decision to use or not to use ECT is influenced by patients' characteristics, their disorders, and the attitudes of psychiatric staff and families.

The findings that many countries where ECT is used do not have technical standards, and that many countries that do have such standards lack clear procedures to monitor compliance, are worrisome. Also of concern is the fact that only a minority of countries reported the use of anesthesia and muscle relaxants in all institutions giving ECT. The causes of this last situation require urgent exploration to determine which of a variety of potential actions-such as providing training and ensuring the availability of anesthesia-are necessary for improvement. The lesser use of anesthesia and muscle relaxants in public institutions, which tend to serve patients from less privileged social classes, points to a pressing need for change.

Administration of ECT to patients without their prior knowledge was reported in an earlier study conducted in Uruguay (4). Needless to say, respect for the human rights of the patient necessitates obtaining informed consent for all medical interventions, especially when they involve riskas, for example, the use of ECT in pregnancy (13). Considerable progress has recently been made in promoting human rights in Latin America, as evidenced by the proceedings of the Conference for the Restructuring of Psychiatric Care, held in Caracas, Venezuela, in 1990 (12), which devoted part of its time to informed consent for ECT. Professional and community sensitivity with regard to this issue has increased, at least in public discourse. Naturally, forward movement will depend on actions both inside and outside the professional area.

The actions countries can take to guarantee appropriate, effective, and humane use of ECT in- 
clude research, consensus-building (see, for example, 14), and creating and monitoring compliance with technical standards. Each demands investment in time and money. Ultimately, they should overcome the negative stereotypes and professional ambivalence still associated with this psychiatric practice.

\section{SINOPSIS}

\section{Uso del tratamiento por electrochoques en América Latina y el Caribe}

En 1995 la OPS/OMS llevó a cabo una encuesta postal para investigar las características del uso del tratamiento por electrochoques (TEC) en América Latina y en el Caribe de habla inglesa y holandesa. Según los resultados de la encuesta, el uso del TEC difiere en las dos subregiones. La técnica se utiliza ampliamente en América Latina y solo esporádicamente en el Caribe. Asimismo, su uso varía dentro de cada país y ha sufrido cambios a lo largo del tiempo. Solamente la mitad de los países de América Latina tienen normas técnicas para la aplicación del TEC. La administración de anestesia y de relajantes musculares durante el mismo y la obtención de consentimiento informado todavía no son prácticas reglamentarias en las instituciones psiquiátricas de América Latina. La toma de medidas para subsanar estos déficit ayudará a borrar la estereotípica imagen negativa que esta intervención suele evocar.

\section{REFERENCES}

1. Menchón Magriña JM, Pons Villanueva A. Historia de la TEC. In: Rojo Rodes JE, Vallejo Ruiloba J, eds. Terapia electroconvulsiva. Barcelona: Masson-Salvat Medicina; 1994: 9-24.

2. Fink M. Electroshock therapy: myths and realities. Hospital Practice 1978; November:77-82.

3. American Psychiatric Association. The practice of electroconvulsive therapy: recommendations for treatment, training, and privileging. Washington, DC: American Psychiatric Press; 1990.

4. DiSegni M, Cusmanich S. Electroshock: estudio de los reparos de los psiquiatras para su uso. Rev Psiquiatr (Uruguay) 1993;4:19-30.

5. Freeman CPL, Kendell RE. ECT: I, Patients' experiences and attitudes. $\mathrm{Br} J$ Psychiatry 1980;137:8-16.
6. Babigian HM, Guttmacher LB. Epidemiologic considerations in electroconvulsive therapy. Arch Gen Psychiatry 1984; 41:246-253.

7. Kramer BA. Use of ECT in California 1977-1983. Am J Psychiatry 1985;142: 1190-1192.

8. Hermann RC, Dorwat RA, Hoover CW, Brody J. Variation in ECT use in the United States. Am J Psychiatry 1995;152: 869-875.

9. Latey RH, Fahey TJ. Some influences on regional variation in frequency of prescription of electroconvulsive therapy. Br J Psychiatry 1988;152:196-200.

10. Lyford Pike A, Otegui J, Savi G, Fernández M. ECT: changing in Uruguay [letter]. Convulsive Ther 1995;11:58-60.

11. Fauli Prats A, Álvarez Martínez JL. Anestesia en la TEC. In: Rojo Rodes JE,
Vallejo Ruiloba J, eds. Terapia electroconvulsiva. Barcelona: Masson-Salvat Medicina; 1994: 101-120.

12. González Uzcátegui R, Levav I. Reestructuración de la atención psiquiátrica: bases conceptuales y guías para su implementación. Washington, DC: Organización Panamericana de la Salud/ Organización Mundial de la Salud; 1991. (Document HPA/MND 1.91)

13. Miller LJ. Use of electroconvulsive therapy during pregnancy. Hosp Community Psychiatry 1994;45:444-451.

14. National Institute of Mental Health Electroconvulsive therapy-consensus conference. JAMA 1985;254:2103-2108. 